\title{
Toxic Effects of Lignocaine on the Circulation
}

\author{
PETER F. BINNION,* M.A., B.M., M.SC., PH.D., M.R.C.P.ED.
}

There is little doubt concerning the efficacy of lignocaine (Xylocaine) in the treatment of many cardiac arrhythmias, particularly during cardiac catheterization (Southworth et al., 1950), during intubation and induction of anaesthesia and cardiac surgery (Weiss, 1960), and after myocardial infarction (Lown et al., 1967 ; Jewitt et al., 1968 ; Spracklen et al., 1968). In spite of the apparent value of the drug there is little information on its haemodynamic effects, and this communication is concerned with evaluating its effect in small doses in man and much larger doses in dogs. This investigation was done to determine whether a continuous infusion of lignocaine could be used in all patients after myocardial infarction to suppress the common ventricular ectopic beats, and possibly act as a prophylactic measure to prevent arrhythmias causing further myocardial deterioration. Lown et al. (1967) expressed the opinion that antrarrhythmic drugs might jeopardize survival after myocardial infarction by reducing myocardial contractile force.

\section{Methods}

\section{Patients}

Four patients (weight 40.6-79.8 kg.) undergoing cardiac catheterization under light barbiturate anaesthesia with a view to possible surgery were investigated. Measurements were taken before and after an intravenous dose of lignocaine (1 mg./ kg.) given over a two-minute period, and 10,20,30, and 60 minutes after starting a lignocaine infusion given with a homemade constant infusion pump $(1 \mathrm{mg} . / \mathrm{min}$. in a volume of $2 \mathrm{ml}$. of isotonic saline; total dose was approximately $120 \mathrm{mg}$. of lignocaine). Conventional catheters were used and transseptal left atrial catheterization was performed with a modified Brockenbrough needle; in one instance left ventricular pressure was measured with a transseptal catheter through the mitral valve (the maximum rate of rise of left ventricular pressure, $\mathrm{dp} / \mathrm{dt}$, was measured and taken as the average of five values determined by a tangent drawn on the steepest part of the pressure tracing ; the rate at which ventricular pressure is developed reflects a fundamental property of contracting myocardium and may be used to study myocardial contractility (Gleason and Braunwald, 1962)). Pressures were measured with Sanborn transducers $5 \mathrm{~cm}$. below the sternal angle and recorded on a Sanborn 560-series polyanalyser. Cardiac output was measured by using indocyanine green dye injected into the pulmonary artery or right ventricle with arterial blood being withdrawn by a Gilford 105-S pump through a Gilford 103-IR densitometer and recorded on a Southern Instruments ultraviolet recorder. Haemodynamic changes are given as percentage changes from control values $(\Delta \%)$.

\section{Dogs}

Six dogs (weight 21.8-29.0 kg.) were anaesthetized with sodium pentobarbitone ( $30 \mathrm{mg} . / \mathrm{kg}$. body-weight) and the experiment was started two hours later, when the cardiovascular - Lecturer in Physiology, the Queen's University of Belfast ; and Con-
sultant in Physiology to the Northern Ireland Hospitals Authority. system is known to be in a stable state (Binnion and Hatcher, 1963). Cardiac output was determined by the dye-dilution method with the use of indocyanine green dye injected into the central venous circulation; arterial blood was withdrawn from the femoral artery by a Gilford 105-S constant withdrawal pump through a Cambridge Instruments cuvette coupled to a Cambridge dye dilution recorder. Central aortic blood pressure was measured through a polyethylene catheter (Portex PP260) by means of a Consolidated Electrodynamics strain gauge transducer (type 4-327-L221) attached to a Devices M.4 recorder. The arterial blood pressure and lead II of the electrocardiogram were recorded during the inscription of the dye curve. Mean arterial blood pressure was calculated from the diastolic pressure plus one-third of the pulse pressure. The Q-T interval was measured with callipers from lead II of the electrocardiogram, and the rate of rise of the central aortic pulse $(\mathrm{dp} / \mathrm{dt}$ ) was measured from a tangential line drawn on the steepest part of the upstroke and the average of no fewer than five measurements taken (this measurement may be related to myocardial contractility).

An intravenous infusion of lignocaine $(10-13.5 \mathrm{mg} . / \mathrm{min}$.) was given with a constant infusion pump, and cardiac output, central aortic pressure, and the electrocardiogram were recorded after 10,20, and 30 minutes of infusion. After a rest period these measurements were recorded before and after a rapid intravenous injection of 200 and $400 \mathrm{mg}$. of lignocaine (given as a $2 \%$ solution), and in one instance after $500 \mathrm{mg}$.

\section{Results}

Infusion into Patients. - There were no consistent changes in any of the cardiovascular measurements (Table I), and the total dose of lignocaine given within the hour varied from 110 to $140 \mathrm{mg}$. There were no subjective or other objective changes in these patients.

TABle I.-Haemodynamic Changes Produced in Four Patients by $1 \mathrm{mg}$. of Lignocaine per Minute After Loading Dose of $1 \mathrm{mg} . / \mathrm{kg}$. Bodyweight

\begin{tabular}{|c|c|c|c|c|c|}
\hline & $\begin{array}{l}\text { Cardiac } \\
\text { Output } \\
(\Delta \%)\end{array}$ & $\begin{array}{l}\text { Heart } \\
\text { Rate } \\
(\Delta \%)\end{array}$ & $\begin{array}{l}\text { Stroke } \\
\text { Volume } \\
(\Delta \%)\end{array}$ & $\begin{array}{c}\text { Mean } \\
\text { Arterial } \\
\text { Blood } \\
\text { Pressure } \\
(\triangle \%)\end{array}$ & $\begin{array}{c}\text { Total } \\
\text { Systemic } \\
\text { Resistance } \\
(\Delta \%)\end{array}$ \\
\hline $\begin{array}{l}10 \mathrm{~min} . \text { of infusion } . . \\
20 \mathrm{~min} \text {. of infusion } . \\
30 \mathrm{~min} \text {. of infusion } . . \\
60 \mathrm{~min} \text {. of infusion } . .\end{array}$ & $\begin{array}{l}-2.4 \\
-0.7 \\
+1.7 \\
-8.2\end{array}$ & $\begin{array}{l}-0.5 \\
-3.2 \\
+1.9 \\
-1.3\end{array}$ & $\begin{array}{l}-4 \cdot 7 \\
-3 \cdot 3 \\
+2 \cdot 0 \\
-6.5\end{array}$ & $\begin{array}{l}-0.6 \\
+2.4 \\
+1.3 \\
-4.9\end{array}$ & $\begin{array}{l}+2.4 \\
+3.8 \\
-0.5 \\
-0.8\end{array}$ \\
\hline
\end{tabular}

Infusion into Anaesthetized Dogs.-The dose was approximately 25 times greater than that given to the patients, and this caused a small fall in arterial blood pressure which was progressive $(11 \%$ fall in mean pressure at end of the 30 -minute infusion) and a progressive bradycardia (fall of $18.4 \%$ in heart rate at end of infusion). There was an increase in cardiac output, but total peripheral resistance fell only after 30 minutes' infusion. The increase in the $\mathrm{Q}-\mathrm{T}$ interval of the electrocardiogram was small, but there was a distinct fall in central aortic $\mathrm{dp} / \mathrm{dt}$ (Tables II and III). However, in spite of the large doses used the cardiovascular changes produced were not severe. 
Injection of Lignocaine in Patients.-An injection of $1 \mathrm{mg}$. of lignocaine per $\mathrm{kg}$. body-weight produced no effect on the measurements except in one patient where there was a transient fall in left ventricular dp/dt from 1,518 to $1,363 \mathrm{~mm}$. $\mathrm{Hg} / \mathrm{sec}$. This dose of lignocaine given over a two-minute period causes a small reduction in myocardial contractility.

TABLB II.-Effect of Infusing Lignocaine at 10-13.5 mg./min. Into Anaesthetized Dogs

\begin{tabular}{|c|c|c|c|c|c|c|c|}
\hline \multirow{2}{*}{ Dog } & & \multicolumn{3}{|c|}{$\begin{array}{l}\text { Arterial Blood Pressure } \\
(\mathrm{mm} . \mathrm{Hg})\end{array}$} & \multirow{2}{*}{$\begin{array}{c}\text { E.C.G. } \\
\text { Rate } \\
\text { (Com- } \\
\text { plexes/ } \\
\text { min.) }\end{array}$} & \multirow{2}{*}{ 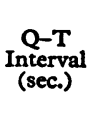 } & \multirow{2}{*}{$\begin{array}{c}\text { Max. } \\
\text { Aortic } \\
\text { dp/dt } \\
\text { (mm. Hg) } \\
\text { sec.) }\end{array}$} \\
\hline & & $\begin{array}{l}\text { Sys- } \\
\text { tolic }\end{array}$ & Mean & $\begin{array}{l}\text { Dias- } \\
\text { tolic }\end{array}$ & & & \\
\hline 47 & $\begin{array}{l}\text { Control } \\
10 \text { min. of } \\
\text { infusion }\end{array}$ & $\begin{array}{l}170 \\
176 \\
171\end{array}$ & $\begin{array}{l}154 \\
156 \\
152\end{array}$ & $\begin{array}{l}146 \\
146\end{array}$ & $\begin{array}{l}130 \\
120\end{array}$ & & \\
\hline & $\begin{array}{ll}20 & \prime \prime\end{array}$ & 172 & 152 & $\begin{array}{l}142 \\
142\end{array}$ & 111 & & \\
\hline 55 & $\begin{array}{l}\text { Control } \\
10 \text { min. of } \\
\text { infusion }\end{array}$ & $\begin{array}{l}205 \\
200 \\
174\end{array}$ & $\begin{array}{l}165 \\
160 \\
141\end{array}$ & $\begin{array}{l}145 \\
140 \\
124\end{array}$ & $\begin{array}{l}167 \\
159 \\
148\end{array}$ & $\begin{array}{l}0.22 \\
0.20 \\
0.20\end{array}$ & $\begin{array}{l}1,550 \\
1,760 \\
1,347\end{array}$ \\
\hline & $\begin{array}{ll}20 & \prime \prime\end{array}$ & 150 & 122 & 108 & 140 & 0.22 & 1,127 \\
\hline & $\begin{array}{l}\text { Control } \\
10 \text { min. }\end{array}$ & $\begin{array}{l}223 \\
231\end{array}$ & $\begin{array}{l}202 \\
204\end{array}$ & $\begin{array}{l}190 \\
191\end{array}$ & $\begin{array}{l}195 \\
161\end{array}$ & $\begin{array}{l}0.21 \\
0.22\end{array}$ & $\begin{array}{r}1,297 \\
790\end{array}$ \\
\hline 50 & $\begin{array}{ll}20 & \text { intusion } \\
30 & \#\end{array}$ & $\begin{array}{l}225 \\
205\end{array}$ & $\begin{array}{l}198 \\
183\end{array}$ & $\begin{array}{l}185 \\
172\end{array}$ & $\begin{array}{l}140 \\
138\end{array}$ & $\begin{array}{l}0.22 \\
0.22\end{array}$ & $\begin{array}{l}673 \\
466\end{array}$ \\
\hline 57 & $\begin{array}{l}\text { Control } \\
10 \text { min. of } \\
\text { infusion }\end{array}$ & $\begin{array}{l}234 \\
235 \\
227\end{array}$ & $\begin{array}{l}211 \\
208 \\
201\end{array}$ & $\begin{array}{l}199 \\
194 \\
188\end{array}$ & $\begin{array}{l}187 \\
183 \\
174\end{array}$ & $\begin{array}{l}0.19 \\
0.20 \\
0.20\end{array}$ & $\begin{array}{l}1,951 \\
1,877 \\
872\end{array}$ \\
\hline & $\begin{array}{ll}20 & \prime \\
30 & \#\end{array}$ & 218 & 194 & 182 & 159 & 0.22 & 764 \\
\hline 58 & $\begin{array}{l}\text { Control } \\
10 \text { min. of } \\
\text { infusion }\end{array}$ & $\begin{array}{l}213 \\
218 \\
221\end{array}$ & $\begin{array}{l}189 \\
190 \\
192\end{array}$ & $\begin{array}{l}177 \\
176 \\
177\end{array}$ & $\begin{array}{l}168 \\
154 \\
148\end{array}$ & $\begin{array}{l}0.23 \\
0.24 \\
0.26\end{array}$ & $\begin{array}{l}963 \\
945 \\
898\end{array}$ \\
\hline & $30 \quad "$ & 216 & 189 & 175 & 146 & 0.27 & 831 \\
\hline
\end{tabular}

TABLB III.-Haemodynamic Changes Induced in Anaesthetized Dogs Infused with Lignocaine (13.5 mg./min.)

\begin{tabular}{|c|c|c|c|c|c|}
\hline & $\begin{array}{c}\text { Cardiac } \\
\text { Output } \\
(\Delta \%)\end{array}$ & $\begin{array}{c}\text { Heart } \\
\text { Rate } \\
(\Delta \%)\end{array}$ & $\begin{array}{c}\text { Stroke } \\
\text { Volume } \\
(\Delta \%)\end{array}$ & $\begin{array}{c}\text { Mean } \\
\text { Arterial } \\
\text { Blood } \\
\text { Pressure } \\
(\triangle \%) \\
\end{array}$ & $\begin{array}{c}\text { Total } \\
\text { Systemic } \\
\text { Resistance } \\
(\Delta \%) \\
(\Delta \%)\end{array}$ \\
\hline $\begin{array}{l}10 \text { min. of infusion } .: \\
20 \text { min. of infusion } \\
30 \text { min. of infusion }\end{array}$ & $\begin{array}{r}+10.3 \\
+3.9 \\
+14.3\end{array}$ & $\begin{array}{r}-8 \cdot 0 \\
-14 \cdot 6 \\
-18 \cdot 4\end{array}$ & $\begin{array}{l}+21 \cdot 2 \\
+15.8 \\
+39 \cdot 1\end{array}$ & $\begin{array}{r}-0.4 \\
-4.8 \\
-10.8\end{array}$ & $\begin{array}{r}+2.5 \\
+9.3 \\
-15.4\end{array}$ \\
\hline
\end{tabular}

Large Doses of Lignocaine Injected into Dogs.-Rapid injections of 200 and $400 \mathrm{mg}$. caused a marked reduction in both arterial blood pressure and maximum aortic $\mathrm{dp} / \mathrm{dt}$ (Table IV), but this is of a relative transient nature. In dog 54 an injection of $500 \mathrm{mg}$. of lignocaine intravenously caused a fall in heart rate from 135 to $102 / \mathrm{min}$. after 50 seconds and of $105 /$ min. after 180 seconds. Shortly after this the previously normal sinus rhythm changed suddenly to an idioventricular rhythm, and at 225 seconds this deteriorated into coarse ventricular fibrillation and then rapidly to ventricular asystole (Table IV).

\section{Discussion}

This communication and the work of others (Harrison et al., 1963 ; Jewitt et al., 1968) show that lignocaine given as an intravenous infusion of $1 \mathrm{mg} . / \mathrm{min}$. does not have any noticeable haemodynamic effects in man. This dose is capable of reducing the incidence of ventricular ectopic beats after myocardial infarction (Jewitt et al., 1968) ; hence it is appropriate now to consider whether clinical trials should be instituted in which all patients in an intensive care unit after myocardial infarction are given an infusion of lignocaine to determine whether it will prevent the occurrence of ventricular arrythmias. These arrhythmias are known to have a deleterious effect on the circulation (McIntosh and Morris, 1966) and would tend to compound the myocardial damage. Lown et al. (1967) stated that owing to the myocardial depression produced by antiarrhythmic drugs their prophylactic use in myocardial infarction is not justified. This article shows that this statement is not justified. Lignocaine infusions should be given at a constant rate (preferably by a constant infusion pump), for even $1 \mathrm{mg}$. of lignocaine per $\mathrm{kg}$. body-weight given over a twominute period can reduce left ventricular contractility slightly.

Even when infused at a rate 25 times greater the deterioration in arterial blood pressure and heart rate in anaesthetized dogs is only moderate, and if ventricular arrhythmias cannot be controlled with $1 \mathrm{mg}$. of lignocaine per minute it would appear safe to increase this dose, but only with arterial blood pressure being constantly monitored, especially if large injections of lignocaine are used (this is necessary in view of the sudcien change from sinus rhythm to ventricular fibrillation which occurred in one dog). Severe depression of the arterial blood pressure is seen in anaesthetized dogs given a sudden injection of $400 \mathrm{mg}$. of lignocaine, which is just less than $20 \mathrm{mg} . / \mathrm{kg}$. body-weight. The reduction of arterial blood pressure is shortlived, so there is a large safety factor present when using this drug. The electrocardiogram is not a good guide to the presence of a severe toxic depression of the circulation, for an idioventricular rhythm and ventricular fibrillation can occur suddenly from preceding normal sinus rhythm. If large doses are to be infused, arterial blood pressure measurements are mandatory.

\section{Summary}

In man an infusion of intravenous lignocaine in a dose of $1 \mathrm{mg} . / \mathrm{min}$. has no noticeable cardiovascular effects when given for up to 60 minutes. In anaesthetized dogs $10-13.5 \mathrm{mg} . / \mathrm{min}$.

TABLB IV-Effect of Rapid Intravenous Injection of Lignocaine

\begin{tabular}{|c|c|c|c|c|c|c|c|}
\hline \multirow{2}{*}{ Dog } & \multirow{2}{*}{$\begin{array}{c}\text { Time after } \\
\text { Injection }\end{array}$} & \multicolumn{3}{|c|}{$\begin{array}{l}\text { Arterial Blood Pressure } \\
(\mathrm{mm} . \mathrm{Hg})\end{array}$} & \multirow{2}{*}{$\begin{array}{l}\text { E.C.G. } \\
\text { Rate } \\
\text { (Com. } \\
\text { plexes/ } \\
\text { min.) }\end{array}$} & \multirow{2}{*}{$\underset{\text { (sec.) }}{\text { Q-T }}$} & \multirow{2}{*}{$\begin{array}{c}\text { Max. } \\
\text { Aortic } \\
\text { dp/dt } \\
\text { (mm. Hg/ } \\
\text { sec.) }\end{array}$} \\
\hline & & $\begin{array}{l}\text { Sys- } \\
\text { tolic }\end{array}$ & Mean & $\begin{array}{l}\text { Dias- } \\
\text { tolic }\end{array}$ & & & \\
\hline \multicolumn{8}{|c|}{200 mg. Lignocaine } \\
\hline & $\begin{array}{l}\text { Control } \\
\text { End of }\end{array}$ & 170 & 137 & 120 & 137 & 0.21 & 1,320 \\
\hline 55 & $\begin{array}{l}\text { injection } \\
1 \\
2 \\
3 \\
5 \\
7\end{array}$ & $\begin{array}{l}104 \\
110 \\
118 \\
128 \\
139 \\
149\end{array}$ & $\begin{array}{r}79 \\
91 \\
99 \\
107 \\
115 \\
123\end{array}$ & $\begin{array}{r}66 \\
81 \\
89 \\
97 \\
103 \\
110\end{array}$ & $\begin{array}{l}135 \\
123\end{array}$ & 0.23 & 511 \\
\hline & $\begin{array}{l}\text { Control } \\
\text { End of }\end{array}$ & 225 & 198 & 184 & 134 & 0.23 & 682 \\
\hline 56\{ & $\begin{array}{l}\text { injection } \\
3 \\
6 \\
10 \\
15\end{array}$ & $\begin{array}{l}173 \\
210 \\
226 \\
209 \\
211\end{array}$ & $\begin{array}{l}155 \\
186 \\
199 \\
186 \\
187\end{array}$ & $\begin{array}{l}146 \\
174 \\
185 \\
174 \\
175\end{array}$ & $\begin{array}{l}136 \\
124 \\
126 \\
122 \\
130\end{array}$ & $\begin{array}{l}0.24 \\
0.24 \\
0.24\end{array}$ & $\begin{array}{r}668 \\
632 \\
642 \\
800 \\
692 \\
2,165\end{array}$ \\
\hline 57 & $\begin{array}{l}\text { Control } \\
1 \\
2 \\
5\end{array}$ & $\begin{array}{l}231 \\
172 \\
193 \\
221\end{array}$ & $\begin{array}{l}206 \\
151 \\
173 \\
198\end{array}$ & $\begin{array}{l}194 \\
141 \\
163 \\
186\end{array}$ & $\begin{array}{l}178 \\
145 \\
151 \\
157\end{array}$ & $\begin{array}{l}0 \cdot 20 \\
0 \cdot 22 \\
0 \cdot 22 \\
0 \cdot 21\end{array}$ & $\begin{array}{r}2,165 \\
1,137 \\
1,483 \\
824\end{array}$ \\
\hline 58 & $\begin{array}{l}\text { Control } \\
1 \\
2 \\
5 \\
10\end{array}$ & $\begin{array}{l}208 \\
203 \\
209 \\
216 \\
216\end{array}$ & $\begin{array}{l}183 \\
188 \\
179 \\
189 \\
189\end{array}$ & $\begin{array}{l}170 \\
166 \\
164 \\
175 \\
176\end{array}$ & $\begin{array}{l}153 \\
141 \\
137 \\
140 \\
141\end{array}$ & $\begin{array}{l}0.25 \\
0.26 \\
0.26 \\
0.26 \\
0.28\end{array}$ & $\begin{array}{l}810 \\
714 \\
730 \\
746 \\
764\end{array}$ \\
\hline \multicolumn{8}{|c|}{$400 \mathrm{mg}$. Lignocaine } \\
\hline 56\{ & $\begin{array}{l}\text { Control } \\
1 \\
3 \\
5 \\
8 \\
12\end{array}$ & $\begin{array}{l}225 \\
112 \\
156 \\
193 \\
232 \\
204\end{array}$ & $\begin{array}{l}200 \\
101 \\
139 \\
172 \\
201 \\
179\end{array}$ & $\begin{array}{r}187 \\
96 \\
131 \\
162 \\
186 \\
166\end{array}$ & $\begin{array}{l}111 \\
113 \\
110\end{array}$ & $\begin{array}{l}0.24 \\
0.27 \\
0.26 \\
0.26 \\
0.26 \\
0.25\end{array}$ & $\begin{array}{l}730 \\
376 \\
452 \\
426 \\
617 \\
620\end{array}$ \\
\hline 57 & $\begin{array}{l}\text { Control } \\
1 \\
2 \\
5 \\
10\end{array}$ & $\begin{array}{l}232 \\
103 \\
115 \\
179 \\
208\end{array}$ & $\begin{array}{r}209 \\
91 \\
104 \\
164 \\
187\end{array}$ & $\begin{array}{r}196 \\
85 \\
98 \\
156 \\
177\end{array}$ & $\begin{array}{l}192 \\
133 \\
133 \\
135 \\
144\end{array}$ & $\begin{array}{l}0.19 \\
0 \cdot 22 \\
0 \cdot 25 \\
0 \cdot 25 \\
0 \cdot 22\end{array}$ & $\begin{array}{r}1,469 \\
731 \\
706 \\
780 \\
1,013\end{array}$ \\
\hline 60\{ & $\begin{array}{l}\text { Control } \\
1^{\frac{1}{2}} \\
3 \\
5 \\
10\end{array}$ & $\begin{array}{l}216 \\
107 \\
129 \\
174 \\
196 \\
217\end{array}$ & $\begin{array}{r}186 \\
88 \\
103 \\
145 \\
164 \\
186\end{array}$ & $\begin{array}{r}171 \\
79 \\
98 \\
131 \\
148 \\
170\end{array}$ & $\begin{array}{l}187 \\
137 \\
143 \\
150 \\
155 \\
163\end{array}$ & $\begin{array}{l}0.21 \\
0.28 \\
0.27 \\
0.26 \\
0.25 \\
0.24\end{array}$ & $\begin{array}{r}2,610 \\
885 \\
1,232 \\
1,553 \\
1,847 \\
1,781\end{array}$ \\
\hline \multicolumn{8}{|c|}{$500 \mathrm{mg}$. Lignocaine } \\
\hline 54\{ & $\begin{array}{l}\text { Control } \\
1 \\
3 \\
3 \frac{1}{4} \\
4 \frac{1}{6}\end{array}$ & & & & \begin{tabular}{|c|}
135 \\
102 \\
105 \\
Sinoatr \\
ventr \\
Idioven \\
mina \\
fibrill \\
ventr
\end{tabular} & $\begin{array}{l}\text { al block } \\
\text { cular rhyt } \\
\text { tricular } \mathrm{rh} \\
\text { ing in } v \\
\text { ation an } \\
\text { cular asyst }\end{array}$ & $\begin{array}{l}\text { with idio- } \\
\text { whm. } \\
\text { aythm ter- } \\
\text { aentricular } \\
\text { vd then } \\
\text { itole }\end{array}$ \\
\hline
\end{tabular}


causes a moderate reduction in heart rate, arterial blood pressure, and central aortic $\mathrm{dp} / \mathrm{dt}$, but a reduction in total systemic resistance occurred only at 30 minutes of infusion. A slight reduction in left ventricular $\mathrm{dp} / \mathrm{dt}$ was seen in one patient given $1 \mathrm{mg}$. $/ \mathrm{kg}$. body-weight over a two minute period. Doses of $200-500 \mathrm{mg}$. of lignocaine given as a rapid injection into anaesthetized dogs cause a marked fall in arterial blood pressure and maximum aortic $\mathrm{dp} / \mathrm{dt}$, and in one instance ventricular fibrillation was produced suddenly and without warning. The electrocardiogram is a poor guide to toxic effects, and arterial blood pressure is more useful and probably mandatory when larger doses are infused. Lignocaine infusion $(1 \mathrm{mg} . / \mathrm{min}$.) should be given a clinical trial in all patients with myocardial infarction, for it has no marked haemodynamic effects in this dose and may well suppress the onset of potentially harmful ventricular arrhythmias.

AdDENDUM.-A 200-mg. rapid injection of lignocaine (dog 68) caused a fall in maximum left ventricular $d p / d t$ from 2,122 $\mathrm{mm} . \mathrm{Hg} / \mathrm{sec}$. to 1,492 (15 seconds later), 1,673 (30 seconds later), and 2,143 (two minutes later). In one patient an injection of lignocaine $1 \mathrm{mg}$. $/ \mathrm{kg}$. over two minutes caused a fall in left ventricular $\mathrm{dp} / \mathrm{dt}$ from 1,920 to $1,495 \mathrm{~mm}$. $\mathrm{Hg} / \mathrm{sec}$. $(\Delta \%=-22.1)$.

Reprint requests to P. F. Binnion, Cardiovascular Unit, Belfast City Hospital, Belfast BT9 17JB.

\section{REPERENCES}

Binnion, P. F., and Hatcher, J. D. (1963). Circular. Res., 12, 393. Gleason, W. L., and Braunwald, E. (1962). $尹$. clin. Invest., $41,80$. Harrison, D. C., Sprouse, J. H., and Morrow, A. G. (1963).' Circulation, $28,486$.

Jewitt, D. E., Kishon, Y., and Thomas, M. (1968). Lancet, 1, 266.

Lown, B., Fakhro, A. M., Hood, W. B., and Thorn, G. W. (1967). 3. Amer med. Ass., 199, 188.

McIntosh, H. D., ana Morris, J. J. (1966). Progr. cardiovesc. Dis., 8, 330 .

Southworth, J. L., McKusick, V. A., Pierce, E. C., and Rawson, F. L. (1950). Ұ. Amer. med. Ass., 143, 717 .

Spracklen, F. H. N., Kimerling, J. J., Besterman, E. M. M., and Litchfield, J. W. (1968). Brit. med. F., 1, 89.

Weiss, W. A. (1960). Anesth. Analg. curr. Res., 39, 369.

\section{Medical Memoranda}

\section{Hyperkalaemic Periodic Paralysis Starting at Age 48}

Brit. med. F., 1968, 2, 472-473

Three main types of periodic paralysis are recognizedhypokalaemic (the commonest), hyperkalaemic, and the sodium-responsive normokalaemic variety.

Hyperkalaemic periodic paralysis, or adynamia episodica hereditaria, was described in full by Gamstorp (1956). It is a hereditary disease that starts in infancy or childhood, is at its worst during adolescence, and, apart from pregnancy, tends to subside later in life (McArdle, 1963). It is characterized by periodic attacks of paralysis lasting 30 to 40 minutes, and typically occurring during rest after exercise. Attacks are usually diurnal and frequent, though nocturnal attacks of longer duration and greater severity may also occur. They are often precipitated by fasting, emotional states, cold weather, and intercurrent infections (Layzer, Lovelace, and Rowland, 1967). Episodes may be aborted by exercise or at times by ingestion of carbohydrate (van't Hoff, 1962). Unlike the hypokalaemic variety death never occurs during a spontaneous attack of hyperkalaemic periodic paralysis (Helweg-Larsen, Hauge, and Sagild, 1955).

A high serum potassium during attacks is diagnostic of the condition. Other electrolyte values are usually normal ; a few otherwise typical cases of hyperkalaemic periodic paralysis do have hypocalcaemia during attacks (Layzer et al., 1967).

\section{CASE History}

A 48-year-old man, the second of a family of 10 children, was admitted to hospital in January 1966 with an acute anterior infarct for which he was treated. He was discharged four weeks later. During his stay in hospital he was found to be diabetic, and accordingly was put on a diabetic diet.

Some time after discharge he started having attacks of generalized weakness at the rate of one a week. They usually occurred a short time after exertion. He noticed that when he stuck to his diabetic diet attacks tended to be more frequent. As they were occurring in a background of conjugal troubles a hysterical origin was not excluded. Attacks persisted, and he was asked to call at the clinic, where he obliged by having an attack while sitting in the waitingroom. Admission to hospital was recommended but he was not restricted to bed. Further diurnal paralytic attacks occurred without any special rhythm. However, when an attack occurred he vsually had one or two similar episodes on the same day.
He was conscious of an impending attack, because it was preceded by paraesthesiae and weakness ascending both lower limbs, and by a sensation of precordial discomfort. Weakness soon involved trunk muscles, upper limbs, and neck muscles. He became terrified during attacks but never lost consciousness, and had full control of sphincters. Speech and respiratory muscles were always spared. He found difficulty in moving his eyes. Episodes were over within 20 to 30 minutes, and the lower limbs were the last to recover. During attacks he was unable to raise the lower and upper limbs and the head. Tendon reflexes were diminished but not absent. Both plantars were flexor. Muscles were not painful or tender. Cranial nerves were not involved. Sensation was unimpaired.

Investigations were carried out in three separate attacks. On 2 November 1966 the serum $\mathrm{Na}$ was $130 \mathrm{mEq} /$., serum $\mathrm{K} 9$ $\mathrm{mEq} / \mathrm{l}$., plasma $\mathrm{Cl} 94 \mathrm{mEq} / \mathrm{l}$., serum $\mathrm{Ca} 4.5 \mathrm{mEq} / \mathrm{l}$., and blood glucose $155 \mathrm{mg} . / 100 \mathrm{ml}$. At 12 noon on 25 May 1967 the serum $\mathrm{Na}$ was $133 \mathrm{mEq} / \mathrm{l}$, serum K $10 \mathrm{mEq} / 1$, plasma $\mathrm{Cl} 102 \mathrm{mEq} / 1$, serum $\mathrm{Ca} 4.5 \mathrm{mEq} / \mathrm{l}$, and blood glucose $171 \mathrm{mg} . / 100 \mathrm{ml}$. At 4 p.m. on 25 May the serum $\mathrm{Na}$ was $140 \mathrm{mEq} / 1$., serum $\mathrm{K} 7.3$ $\mathrm{mEq} / \mathrm{l}$., plasma $\mathrm{Cl} 108 \mathrm{mEq} / \mathrm{l}$., serum $\mathrm{Ca} 4.8 \mathrm{mEq} / \mathrm{l}$, and blood glucose $109 \mathrm{mg} . / 100 \mathrm{ml}$.

Between attacks the patient showed no evidence of residual weakness. Investigations carried out between attacks showed: haemoglobin $15.1 \mathrm{~g} . / 100 \mathrm{ml}$., blood urea $33 \mathrm{mg} . / 100 \mathrm{ml}$., serum $\mathrm{Na} 132-146 \mathrm{mEq} / 1$., serum $\mathrm{K}$ 3.7-5 mEq/1., and plasma $\mathrm{Cl}$ 90-100 $\mathrm{mEq} / \mathrm{l}$. $X$-ray examination of chest showed no appreciable disease. Muscle biopsy (taken from the gastrocnemius muscle between attacks) showed no evidence of vacuoles, the only slightly unusual features being a few areas where there seemed to be a possible excess of intracellular nuclei and a single "ringed" fibre (Ringbinden). In the pathologist's view the findings were within normal limits. Electromyography was not carried out, as facilities were not available locally.

The patient was given chlorothiazide $2 \mathrm{~g}$. daily from December 1966 to the end of March 1967, and during that period he had no attacks. When treatment was stopped, a recurrence followed. In the beginning of May he became incapacitated once more, and admission to hospital was again suggested. Further attacks occurred during this latter period. He was restarted on chlorothiazide, and has remained well controlled.

\section{Discussion}

Hyperkalaemic periodic paralysis is a very uncommon condition, for the diagnosis of which certain criteria have to be fulfilled. We believe that the above case satisfies these criteria. The periodic attacks which occur during rest after exercise, and their precipitation by emotional states, are typical. The duration of attacks and their spontaneous remission after 30 to 40 minutes are also characteristic. 